\title{
Domestic Violence from Framming Theory
}

\author{
Resti Nurfaidah $^{\mathbf{1}}$ \\ \{1sineneng1973@gmail.com\} \\ ${ }^{1}$ Balai Bahasa Jawa Barat
}

\begin{abstract}
What happened to the domestic sphere? So, its could be seen as a dangerous zone, especially for women and children as seen on these three short stories: "Sebelah Tangan untuk Ibu", "Surat Anak Aborsi", and "Dunia Setelah Senja". It was conducted through descriptive comparative analysis method in order to map the late differencesof the violence itself. To ease the exploration of those aspect on such data, it need to frame three important point, such as women as actors, children as victim, and tools of violence., through Pan \& Kosicki framing and Hall concept. It was found that there were several reason of delivering the violence inside domestic sphere. High pressure from social site, unsupported surroundings, and bad relationshipness, were reasons of appearance of its violence.
\end{abstract}

Keywords: framing, women, children, victim, actor

\section{Introduction}

The domestic violence was eternal phenomenon in every generation, in our society. Domestic sphere, then, cannot be considered a friendly or safest area, especially for women and children, when it was unable to be protection provide. Domestic lately became the most dangerous sphere for them--in certain situations, such as murder. The following cases were quite astonishing to the public at the time--all were based on the domestic violence: Aniek Qoriah Sriwijaya[1], Andrea Yates [2][3], and series of other female offenders. Certain conditions in domestic area involved female killers with children as victims.So surprisingly, there were many writer's high interests to write the theme of a similar case into their literary works, such as these short stories: "Sebelah Tangan untuk Ibu"[4], "Surat Anak Aborsi" [5], and "Dunia Setelah Senja" [6].

\section{Research Method}

This paper would described observations of violence in domestic areas involving women as killers and children as victims. The method used in this study was a comparative description analysis:(1) selecting data--those short stories that raised the theme of murder in public spaces, as well as involving women as killers and children as victims;(2) comparing data; organized data by applicating the concept of framing[7] from Pan \& Kosicki[8]. This operated four structural dimension of the text as framing device: syntaxis, script, thematic, and 
rhetoric. Syntaxis related to the news scheme (such as: headline, lead, background information, quotes, sources, statements, conclusions), script related to News comphrehensiveness through $5 \mathrm{~W}+1 \mathrm{H}$ question; thematic related to Detail, sentence intentions and its relations, nominalisation between sentences, coherence, sentence form, pronouns (such as: paragraph, proposition) and rhetoric which was related to lexicon, graphics, metaphors, presuppositions, such as words, idioms, pictures, or graphics.The ending of framing was closely related into representation. Here, I used Hall's representation [9]. He restricted representation as a process generated and exchanged meanings among intercultural members through the usage of language, sign, and illustration which represented things[9].In Hall connected to these famous two: mental and language representation. Though the descriptive comparative analysis, the elect corpus were welleksplorated and rearranged into a paper entitled "Domestic Violence from Framming Theory".

\section{Results And Discussion}

\subsection{Female Killer}

In certain conditions, women had bad social pressure, both in the public and domestic sphere, as stated by Abdullah [10]that the public dichotomy which stated that women were imprisoned in the domestic sphere, while men were freely involved in the public sphere stressed a sign of an unequal social structure. In addition, according to Faruk[11], as cultural objects, women were well-placed in positions that were constantly accepting whatever was proposed, created, and decided by men. In the language of Islam, women, specifically wives, were the "fields" where men planted their seeds. In the language of feminist theory, women were called nature where men built culture. And, although women were the group that deeply lives the culture formed for them and at the same time forms them, in their position as objects, the group had no right to change, only the right to defend it.Women had severe experiences and massive pressure from the surroundings, around the domestic sphere, so that the domain was no longer a safe place anyway. instead, turned into hell for them. In certain conditions, women had radical physical and psychological changes that were severe enough for hermade them scary figures for the people around them.The following framing showed who the killerswere and, also, the causes of the crime.

Tabel 1. Pan \& Kosicki Four Structural Dimension Of The Text On "Sebelah Tangan untuk Ibu"

\begin{tabular}{cl}
\hline Structure & \multicolumn{1}{c}{ Framing Devices } \\
\hline Syntaxis & "Sebelah Tangan untuk Ibu" \\
Script & By: Lina Amalina \\
& Genre: short stories \\
& Publication: Pikiran Rakyat Minggu, 17 Mei 2015, p. 22 \\
& Topic: an adoptive mother does not accept the talent her adopted child has in writing. \\
& he hoped his son would master more in the exact sciences than become a writer. \\
Thematic & "Heh, mau jadi apa kamu? Bisanya hanya menulis dan menulis, sedangkan nilai \\
& matematika kamu merah semua," ujar sang ibu. \\
& "Apa penulis? Mau disimpan dimana muka ibumu ini? Almarhum ayahmu seorang \\
& insinyur. Ibumu ini akuntan. Ibu ingin kamu menjadi ahli matematika!" bentak ibunya \\
Rhetoric & (1)"Heh, mau jadi apa kamu?"; (2) "Mau disimpan di mana muka ibumu ini?"; and \\
& (3) insinyur, akuntan, ahli matematika
\end{tabular}


"Sebelah Tangan untuk Ibu" told about Sanny, an adopted child, who had talent as a writer. However, her talent was unacceptable to the ambition of her adoptive mother who was very fanatical about the world of science. For the mother, Science was everything. She considered social studies was lowest science. For her, Sanny's desire to became a writer was disgrace. Excessive disappointment at Sanny's choice, and her inability to change the child's interest, prompted Ms. Hera, the foster mother, to adopt radical ways to stop Sanny. Slapping, screaming, and series abusive treatment became a routine in Sanny's life.

Tabel 2 Pan \&KosickiFour Structural Dimension of The Text on "SuratAnakAborsi"

\begin{tabular}{cl}
\hline STRUCTURE & FRAMING DEVICES \\
SYNTAXIS & "Surat Anak Aborsi" \\
SCRIPT & $\begin{array}{l}\text { By: Santa Fadhli Anzala Haq } \\
\text { Genre: short stories }\end{array}$ \\
& $\begin{array}{l}\text { Publication: Pikiran Rakyat Minggu, 6November 2016, p. 23 } \\
\text { Topic: an aborted child told about her sadness, dissapointedness, and anger towards } \\
\text { her mother. }\end{array}$ \\
THEMATIC & $\begin{array}{l}\text { Kenapa bunda membuat nanda jadi anak haram dan mengapa bunda mengusir } \\
\text { nanda dari Rahim bunda dan tidak memberi kesempatan nanda hidup di dunia } \\
\text { dan berbakti kepada bunda? }\end{array}$ \\
RHETORIC & anak haram; and mengusir nanda dari rahim bunda (abortion) \\
\hline
\end{tabular}

Nanda represented a fetus aborted by her own mother because of her parents illegal relationship. This story was written from the fetus's perspective and her description of her suffering that occurred after the abortion. Her mother was so in panic, so she do the worst thing in her life. Her unpreparedness of caring child, lostof her self-defend, then made her a killer.

Tabel 3 Pan \&KosickiFour Structural Dimension Of The Texton“DuniaSetelahSenja”

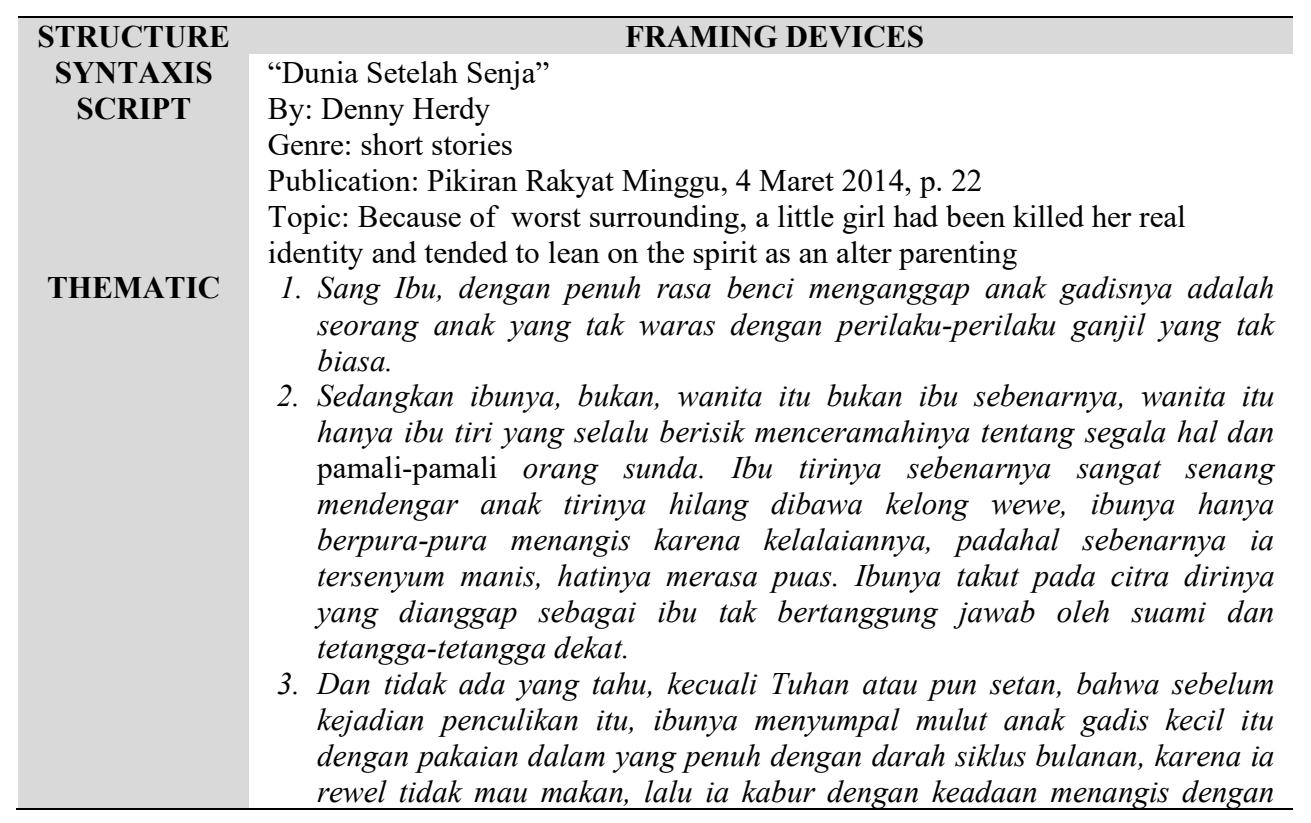




\begin{tabular}{ll}
\hline STRUCTURE & \multicolumn{2}{c}{ FRAMING DEVICES } \\
& mulut belepotan darah lalu bertemu dengan Kelong Wewe dan \\
& membawanya terbang. \\
& 4. Ayahnya menganggap ia sebagai salah satu anaknya yang banyak hingga \\
& ia tidak peduli dengan keberadaannya. Ayah yang selalu dilihatnya sering \\
& kali berganti-ganti wanita, yang selalu mabuk ketika masa gajian datang, \\
& merancau dengan kata-kata kasar, lalu membangunkan semua anggota \\
& keluarga dengan keributan-keributan besar dengan ibunya. \\
RHETORIC & Ibu penuh rasa benci; senang anak tirinya diculik; menyumpal mulut anaknya \\
& karena tidak mau makan; kecewa dengan sikap suaminya; and beban \\
& mengurus anak banyak \\
\hline
\end{tabular}

Mother figures who played a role in changing the personality of the girl was the stepmother. She live das one of her father's wives. Stepmother herself gotlong time depression dued to being ignored and burdened with many children. Children who lived with her were not biological children, mostly step children. For some reason, she really hated her, especially the unusual habit of herself-talking. Even, seeing her stepdaughter was considered crazy, whereas, the girl had been talking to the alter unseen caregivers. The mother's hatred was then complemented by acts of violence from her siblings. In fact, she got sexual abuse from one of her step brothers. The stepmother never cared about her and her suffer. She even wants to send her away.

\subsection{The Children as Victims}

The attitude of the mother who was massively abusive, made Sanny got severe physical and mental pain. Her academic grades declined radically. This further increased the abusiveness of the mother. Climax, Sanny suffered a bad broken arm and had to be amputated. Sanny then got help from a man who later became her husband.

Tabel 4 Pan \&KosickiFour Structural Dimension Of TheTextOn "SebelahTanganuntukIbu"

\begin{tabular}{|c|c|}
\hline STRUCTURE & FRAMING DEVICE \\
\hline SYNTAXIS & "Sebelah Tangan untuk Ibu" \\
\hline \multirow[t]{4}{*}{ SCRIPT } & By: LinaAmalina \\
\hline & Genre: short stories \\
\hline & Publication: Pikiran Rakyat Minggu, 17 Mei 2015, p. 22 \\
\hline & $\begin{array}{l}\text { Topic: an adoptive mother does not accept the talent her adopted child has in } \\
\text { writing. he hoped his son would master more in the exact sciences than become a } \\
\text { writer. }\end{array}$ \\
\hline \multirow[t]{2}{*}{ THEMATIC } & $\begin{array}{l}\text { 1. Sanny terus menangis. Disatukannya serpihan-serpihan kertas yang } \\
\text { dirobek sang ibu Ia peluk kertas itu erat-erat. }\end{array}$ \\
\hline & $\begin{array}{l}\text { 2. Awww! Sanny menjerit sambil memegang tangannya. Ternyata tangan } \\
\text { kanannya patah. Ia tak berdaya lagi menahan sakit yang luar biasa. }\end{array}$ \\
\hline RHETORIC & Menangis, erat-erat, menjerit, dan tangannya patah \\
\hline
\end{tabular}

Suffering from the death was also felt by the fetus. He felt extremely pain during the abortion process. The length of this painful process was reflected in the appearance of several words that appear in the story, among others, when the mother shed nanda(abortion), terriblyill, ached, torny, and like a disgrace that was not appreciated and undesirable. Unpreparedness of the mother was the main reason of the fetusdeath. 
Tabel 5 Pan \&KosickiFour Structural Dimension of The Text on "SuratAnakAborsi"

\begin{tabular}{|c|c|}
\hline STRUCTURE & FRAMING DEVICE \\
\hline SYNTAXIS & "Surat Anak Aborsi" \\
\hline \multirow[t]{4}{*}{ SCRIPT } & By: Santa Fadhli Anzala Haq \\
\hline & Genre: short stories \\
\hline & Publication: Pikiran Rakyat Minggu, 6 November 2016, p. 23 \\
\hline & $\begin{array}{l}\text { Topic: an aborted child told about her sadness, dissapointedness, and anger } \\
\text { towards her mother. }\end{array}$ \\
\hline \multirow[t]{2}{*}{ THEMATIC } & $\begin{array}{l}\text { 1. Walaupun dulu, waktu bunda meluruhkan nanda, sakit banget bunda... } \\
\text { badan nanda rasanya seperti dicabik-cabik... dan keluar sebagai gumpalan } \\
\text { darah yang menjijikan, apalagi hati nanda, nyeri, merasa seperti aib yang } \\
\text { tidak dihargai dan tidak diinginkan. }\end{array}$ \\
\hline & $\begin{array}{l}\text { 2. [...] ... jangan sampai adik-adik nanda mengalami nasib yang sama dengan } \\
\text { nanda, biarlah nanda saja yang merasakan sakitnya ketersia-siaan itu. }\end{array}$ \\
\hline RHETORIC & $\begin{array}{l}\text { Sewaktu bunda meluruhkan nanda; sakit banget; dicabik-cabik; nyeri; and } \\
\text { seperti aib yang tidak dihargai dan tidak diinginkan }\end{array}$ \\
\hline
\end{tabular}

The uncondusiveness of the surroundings completely made the girl's long time depression. She didn't have anyone to lean on. On the contrary, she got the peace amongs those spirits. On the climax, she decided to leave the house and live with spirits. Unfortunately, she had lost the site. It was then changed radically from the forest to the exclusive housing. Along with her frustration, she then decided to suicide, by jumping herself into the gorge.

Tabel 6 Pan \& Kosicki Four Structural Dimension Of The Text on "Dunia Setelah Senja"

\begin{tabular}{|c|c|}
\hline STRUCTURE & FRAMING DEVICE \\
\hline SYNTAXIS & "Dunia Setelah Senja" \\
\hline SCRIPT & By: Denny Herdy \\
\hline & Genre: short stories \\
\hline & Publication: Pikiran Rakyat Minggu, 4 Maret 2014, p. 22 \\
\hline & $\begin{array}{l}\text { Topic: Because of worst surrounding, a little girl had been killed her real } \\
\text { identity and tended to lean on the spirit as an alter parenting }\end{array}$ \\
\hline \multirow[t]{4}{*}{ THEMATIC } & $\begin{array}{l}\text { 1. "Aku ingin tinggal di sini dengan kalian semua selamanya, "ucap gadis } \\
\text { itu berbicara dengan lantang." Aku akan memutuskan mati ketika } \\
\text { purnama datang." }\end{array}$ \\
\hline & $\begin{array}{l}\text { 2. Yang ada hanya tanah merah yang dikeruk hingga rata, mesin-mesin } \\
\text { bulldozer raksasa berwarna kuning, dan sebuah pelang yang bertuliskan } \\
\text { "AKAN DIBANGUN REAL ESTATE" }\end{array}$ \\
\hline & $\begin{array}{l}\text { 3. Gadis itu tak tau apa yang harus ia perbuat karena semua impiannya } \\
\text { sirna dan semua yang ia cintai hilang entah kemana. }\end{array}$ \\
\hline & $\begin{array}{l}\text { 4. Gadis itu meloncat dengan mata terpejam, berharap dunia aka } \\
\text { nmenghitam dan penderitaan akan segera berakhir. }\end{array}$ \\
\hline RHETORIC & $\begin{array}{l}\text { Ingin hidup dengan makhluk halus; hutan berubah fungsi; kecewa; and } \\
\text { bunuh diri }\end{array}$ \\
\hline
\end{tabular}

\subsection{Tools of Violences}

Mastery and memory of any objects inside the sphere became a strenght for the killerthose data. Because of the urge conditions and situations, women gone wild. Theychose closest objects as a tools of execution. In "Sebelah Tangan untuk Ibu" the door was the ultimate tool for Ms. Hera to kill Sanny'stalent as a writer. "Surat Anak Aborsi" did not mention the type of abortion performed by the mother. The story just mentioned abortion in general as a solution 
to overcome immoral acts. "Dunia Setelah Senja" conveyed step by step a psychic murder. Starting from hatred, neglect, physical and psychological torture, which then led the girl to a tragic death: suicide.

Tabel 7 Tools of Violences

\begin{tabular}{llll}
\hline STRUCTURE & & FRAMING DEVICE \\
SYNTAXIS & "Sebelah Tangan untuk Ibu" & $\begin{array}{l}\text { "Surat Anak Aborsi" } \\
\text { RHETORIC }\end{array}$ & $\begin{array}{l}\text { "Door, physical and psychic } \\
\text { physical (abortion) }\end{array}$ \\
& treatments (doctinate) & psychic treatments & $\begin{array}{l}\text { psychic treatments } \\
\text { (isolation) and sexual } \\
\text { abuse }\end{array}$ \\
\hline
\end{tabular}

\subsection{Representation Of Domestic Violences From Framing Theory}

Domestic sphere on those three short stories represented the changing effect of worse surroundings. The sphere couldn't be a safe zone to educate people inside. It was then so dangerous, especially to women and children. Domestic imprisoned the member of family. As Biaggi [12]said:Women became so wild because of her longtime depression, unsolving problem, bad communication with people around - especially children, being away from their hubbies or boyfriends, both in its connotation or denotation meanings. By framing three following points, female killer, children as the victims, and tools of violence, we could understand that domestic sphere, behind its restrictedness, as Chhikara et. al.[13]said provided ease towards following abuses: physical, emotional, sexual harrashment or marital rape, and economic. All were well-collaborated along the disharmonious relationship, unwelcome surroundings, or the incorrect problem solving[14]. Those would be best reason to danger the domestic sphere. The sphere, then, became best source for things, or instruments of executions. On "Sebelah Tangan untuk Ibu", things used by the killer were door, physical and emotional violence (doctrinate). On "Surat Anak Aborsi", killer did physical (abortion) and emotional violence. On "Dunia Setelah Senja", killer did psychical violence (isolation) and sexual harrashment

\section{Conclusion}

The three short stories indicated three following important points in domestic violences, including female killers, children as victims, and the tools of violence. Those main points: female killers, children as victims, and toolsof violence, along with various unresolved problems, unfavorable interpersonal relationships led to the series domestic violences. These would be getting worse by influence of the unconducive environment, the disharmonious relationship between member of the family, also, unability in dealing with problems could cause the danger inside domestic sphere soeasily.

\section{References}

[1] R. A. Fitriawan, “"Pembunuh Tiga Anaknya Terancam Hukuman Mati,"” Tempo.co.

[2] S.S.S, “Kasus Serupa Aniek: Andrea Yates Benamkan 5 Anaknya,” Detiknews.com, 2006.

[3] Deborah W. Denno, "AAndrea Yates: A Continuing About Insanity,"” in The Insanity Defense: Mutidiciplinary Views on Its History, Trends, and Controversies, M. D. White, Ed. California: Praeger, 2017, pp. 367-416.

[4] L. Amalina, “'Sebelah Tangan untuk Ibu," Pikiran Rakyat Minggu, Bandung, p. 22, 17-May- 
2015.

[5] S. F. A. Haq, “"Surat Anak Aborsi,"” Pikiran Rakyat, Bandung, p. 23, 06-Nov-2016.

[6] D. Herdy, “'Dunia Setelah Senja,"” Pikiran Rakyat, Bandung, p. 22, 22-Mar-2014.

[7] S. O. Arowolo, “'Understanding Framming Theory,"” Lagos, 2017.

[8] Zhongdang Pan and G. Kosicki, "Framing Analysis: An Approach to News Discourse," in Communication, United Kingdom: Taylor \& Francis online, vol. 10, 1993, pp. 55-75.

[9] S. Hall, “The Work of Representation," in Representation: Cultural Representation and Signifying Practices, London: Sage Publishing, 1997.

[10] I. Abdullah, Kontruksi dan Reproduksi Kebudayaan. Yogyakarta: Pustaka Pelajar, 2007.

[11] H. T. Faruk, Pengantar Sosiologi Sastra: dari Strukturalisme Genetik sampai Postmodernisme. Yogyakarta: Pustaka Pelajar, 2006.

[12] A. Biaggi, S. Conroy, S. Pawlby, and C. M. Pariante, "Identifying the women at risk of antenatal anxiety and depression: A systematic review," J. Affect. Disord., vol. 191, pp. 62-77, 2016.

[13] P. Chhikara, J. Jakhar, A. Malik, K. Singla, and S. K. Dhattarwal, "Domestic violence: The dark truth of our society," J. Indian Acad. Forensic Med., vol. 35, no. 1, pp. 71-75, 2013.

[14] K. Saddhono, "Language and superdiversity: Indonesians knowledging at home and abroad. By Zane Goebel." Soc. Stu. vol. 12 no.1 pp. 113-118, 2018 